Concentration of Beryillim (Be) and Depleted Uranium (DU) in Marine Fauna and Sediment Samples from Illeginni and Boggerik Islands at Kwajalein Atoll

W. L. Robison, T. F. Hamilton, R. E. Martinelli, S. R. Kehl, T. R. Lindman

February 28, 2005 
This document was prepared as an account of work sponsored by an agency of the United States Government. Neither the United States Government nor the University of California nor any of their employees, makes any warranty, express or implied, or assumes any legal liability or responsibility for the accuracy, completeness, or usefulness of any information, apparatus, product, or process disclosed, or represents that its use would not infringe privately owned rights. Reference herein to any specific commercial product, process, or service by trade name, trademark, manufacturer, or otherwise, does not necessarily constitute or imply its endorsement, recommendation, or favoring by the United States Government or the University of California. The views and opinions of authors expressed herein do not necessarily state or reflect those of the United States Government or the University of California, and shall not be used for advertising or product endorsement purposes.

This work was performed under the auspices of the U.S. Department of Energy by University of California, Lawrence Livermore National Laboratory under Contract W-7405-Eng-48. 


\section{Table of Contents}

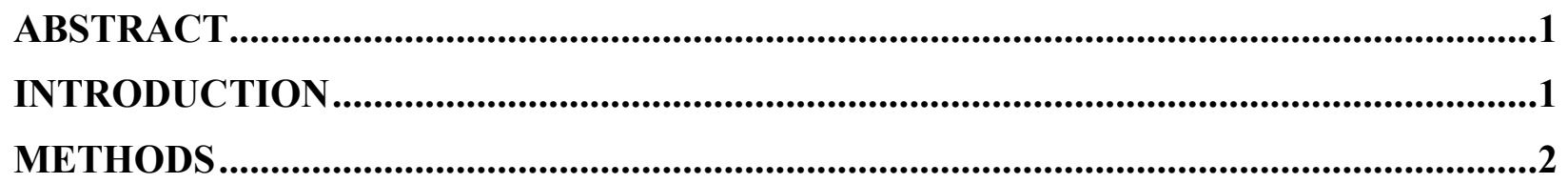

COLLECTION AND INITIAL PREPARATION OF MARINE FAUNA …........................................2

COLLECTION AND INITIAL PREPARATION OF SEDIMENT (BEACH SAND) ...................................

CHEMICAL PROCESSING .....................................................................................

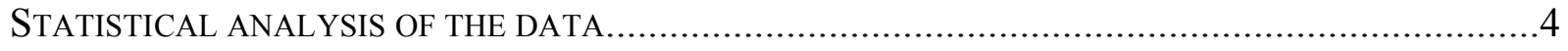

URANIUM CONCENTRATION IN CORAL SOILS.......................................................4

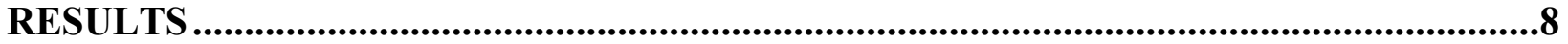

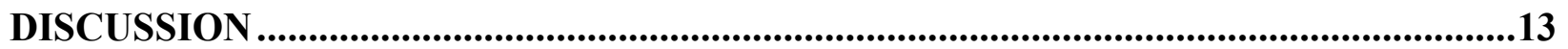

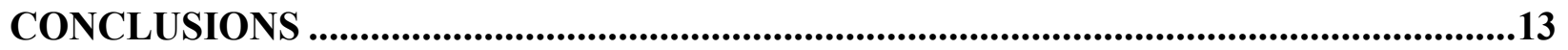

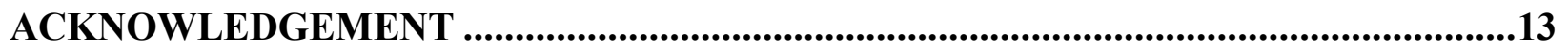

UNITS USED .................................................................................................................13

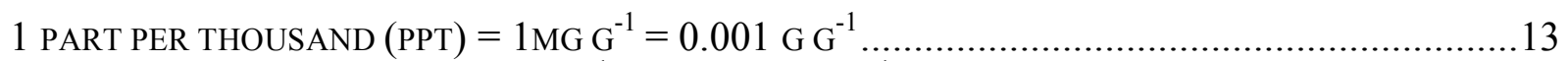

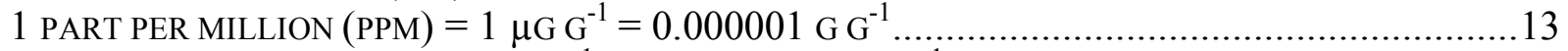

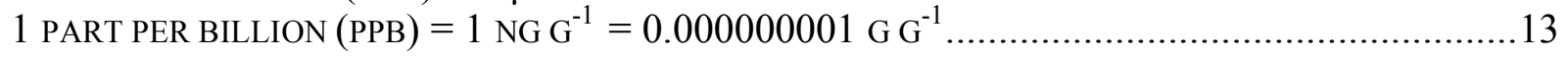

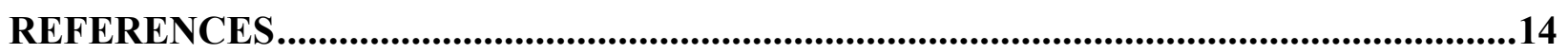

APPENDIX A - ANALYTICAL QUALITY CONTROL DATA ....................................15

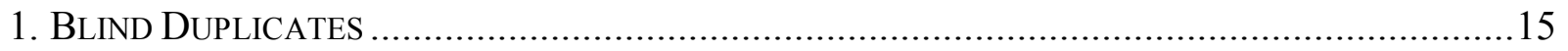

\section{Table of Figures}

Table 1. Marine fauna collected at Illeginni and Boggerik Islands $\quad \mathbf{2}$

Table 2. Location and coordinates of marine sediment (beach sand) collected at Illeginni Island $\quad 4$

Table 3. Concentration of $U$ ( \pm 1 standard error) in corals from global locations

Table 4. The concentration \pm 1 standard error of ${ }^{238} \mathrm{U}$ in coral soil from Majuro, Kwajalein, Wotje, Ponape, and

Truk Atolls

Table 5. The concentration \pm 1 standard error of ${ }^{238} \mathrm{U}$ in soil and lagoon sediments at the northern Marshall Islands 6

Table 6. The concentration \pm 1 standard error of ${ }^{238} \mathrm{U}$ in soil at Enewetak Atolla 7

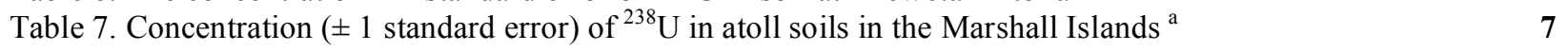

Table 8. Be and $\mathrm{U}$ concentration in all marine fauna at Illeginni and Boggerik Islands $\quad \mathbf{8}$

Table 9. Be and $U$ in marine sediment (beach sand) at Illeginni and Boggerik Islands 9

Table 10. Fe and $\mathrm{Ca}$ concentration in marine sediment at Illeginni and Boggerik Islands $\quad \mathbf{1 0}$

Table 11. Fe concentration in muscle and liver of marine faun $\quad \mathbf{1 1}$

Table 12. Concentration of Fe in muscle of marine fauna (rock crabs deleted) 12 


\title{
Concentration of Beryillim (Be) and Depleted Uranium (DU) in Marine Fauna and Sediment Samples from Illeginni and Boggerik Islands at Kwajalein Atoll
}

\author{
W.L. Robison, T.F. Hamilton, R.E. Martinelli, S.R. Kehl, and T.R. Lindman
}

\begin{abstract}
Lawrence Livermore National Laboratory (LLNL) personnel have supported United States Air Force (USAF) ballistic missile flight tests for about 15 years for Peacekeeper and Minuteman missiles launched at Vandenberg Air Force Base (VAFB). Associated re-entry vehicles (RV's) re-enter at Regan Test Site (RTS) at the U.S. Army base at Kwajalein Atoll (USAKA) where LLNL has supported scoring, recovery operations for RV materials, and environmental assessments.
\end{abstract}

As part of ongoing USAF ballistic missile flight test programs, LLNL is participating in an updated EA being written for flights originating at VFAB. Marine fauna and sediments (beach-sand samples) were collected by United States Fish and Wildlife Service (USFWS), National Marine Fisheries Service (NMFS), and LLNL at Illeginni Island and Boggerik Island (serving as a control site) at Kwajalein Atoll. Data on the concentration of DU (hereafter, $U$ ) and Be in collected samples was requested by USFWS and NMFS to determine whether or not U and $B e$ in RV's entering the Illeginni area are increasing $U$ and Be concentrations in marine fauna and sediments. LLNL agreed to do the analyses for $U$ and Be in support of the EA process and provide a report of the results.

There is no statistically significant difference in the concentration of $U$ and Be in six species of marine fauna from Illeginni and Boggerik Islands ( $p=0.14$ for $U$ and $p=0.34$ for Be). Thus, there is no evidence that there has been any increase in $U$ and Be concentrations in marine fauna as a result of the missile flight test program.

Concentration of $U$ in beach sand at Illeginni is the same as soil and beach sand in the rest of the Marshall Islands and again reflects an insignificant impact from the flight test program.

Beach sand from Illeginni has a mean concentration of Be higher than that from the control site, Boggeik Island. Seven of 21 samples from Ileginni had detectable Be. Four samples had a concentration of Be ranging from 4 to $7 \mathrm{ng} \mathrm{g}^{-1}$ [4 to 7 parts per billion (ppb)], one was 17 ppb, one was 0.14 parts per million (ppm), and one was 0.48 ppm. These extremely low concentrations of an insoluble form of Be again indicate no impact on marine life or human health at Illeginni as a result of the missile flight test program.

Concentration of Fe in marine fauna muscle tissue is much higher at Illeginni Island than at Boggerik Island (control site) as a result of legacy iron piers, dump sites for iron metal along the island, and scrap iron randomly distributed along extensive portions of the reef line as part of programs conducted in the 1960's through 1980 's that were not part of the recent flight test program.

\section{Introduction}

Lawrence Livermore National Laboratory (LLNL) personnel have supported United States Air Force (USAF) ballistic missile flight tests for more than 14 years for Peacekeeper and Minuteman missiles launched at Vandenberg Air Force Base (VAFB). Associated re-entry vehicles (RV's) re-enter at Regan Test Site (RTS) at the U.S. Army base at Kwajalein Atoll (USAKA) where LLNL has supported scoring, recovery operations for RV materials, and environmental assessments. An Environmental Assessment (EA) was written by LLNL for the USAF program in 1988 (Robison and Shinn, 1988), a more extensive EA was written in
1992 (Robison and Cederwall, 1992), and periodic reports have been submitted to USAKA and RTS commanders in the intervening years (Robison and Shinn, 1990; Robison, 1992). Also, letters have been submitted to the commanding officer of USAKA after each supported mission describing whether or not Illeginni Island was affected by the mission and if so, what the recovery operation would entail. Soil samples have been collected for $U$ and Be analysis after every mission where $\mathrm{U}$ and Be were deposited on the island. In each case, hi-volume air samplers were run for a 4 to 5 week period to determine the 
concentration of $\mathrm{U}$ and $\mathrm{Be}$ in air to compare with federal guidelines for the general public.

As part of ongoing USAF ballistic missile flight test programs, LLNL is participating in an updated EA being written for flights originating at VFAB. Marine fauna and sediments (beach-sand samples) were collected by United States Fish and Wildlife Service (USFWS), National Marine Fisheries Service (NMFS), and LLNL at Illeginni Island and Boggerik Island (serving as a control site) at Kwajalein Atoll. Data for concentration of $U$ and Be in collected samples was requested by USFWS and NMFS to determine whether or not $U$ and $\mathrm{Be}$ in RV's entering the Illeginni area are increasing $U$ and Be concentrations in marine fauna and sediments. LLNL agreed to do the analyses for $\mathrm{U}$ and $\mathrm{Be}$ to support the EA process and to provide a report of the results.

\section{Methods}

Collection and initial preparation of marine fauna Different species of fish, eels and crabs were collected from reef flats at Illeginni Island and a control site at Boggerik Islet in August 2004 by staff from the NMF and USFWS. The dates of collection, type of sample, and number of specimens are listed in Table 1. Fauna samples were collected using traps, throw-nets and spears, and packed frozen ready for shipment to LLNL.

Table 1. Marine fauna collected at Illeginni and Boggerik Islands

\begin{tabular}{|c|c|c|c|}
\hline Date & Location & Species & No. \\
\hline \multicolumn{4}{|l|}{ Illeginni Island } \\
\hline 06/08/04 & Ocean side & Snowflake eel (Siderea picta) & 3 \\
\hline 06/09/04 & Ocean side & Snowflake eel (Siderea picta) & 6 \\
\hline 06/09/04 & Ocean side & Rock crab (Graspsus tenuicrustatus) & 15 \\
\hline 06/09/04 & Ocean side & White-tip shark liver (Triaenodon obesus) & $1^{\mathrm{a}}$ \\
\hline 06/09/04 & Ocean side & Black-tip shark liver (Carcharhinus melanopterus) & $1^{\mathrm{a}}$ \\
\hline 06/09/04 & Lagoon side & Snowflake eel (Siderea picta) & 6 \\
\hline 06/09/04 & Lagoon side & Rock crab (Graspsus tenuicrustatus) & 12 \\
\hline $06 / 10 / 04$ & Ocean side & Snowflake eel (Siderea picta) & 1 \\
\hline 06/10/04 & Lagoon side & Snowflake eel (Siderea picta) & 4 \\
\hline 06/10/04 & Lagoon side & Rock crab (Graspsus tenuicrustatus) & 2 \\
\hline $06 / 10 / 04$ & Lagoon side & Farmer fish (Stegastus sp) & 38 \\
\hline & & $\mathrm{a}=$ whole liver & \\
\hline \multicolumn{4}{|c|}{ Boggerik Island, Control Site } \\
\hline $06 / 6,7 / 04$ & Boggerik & Moray eel (Gymnothorax jaranicus) & 1 \\
\hline $06 / 6,7 / 04$ & Boggerik & Snowflake eels (Siderea picta) & 6 \\
\hline $06 / 6,7 / 04$ & Boggerik & Rock crab (Graspsus sp) & 16 \\
\hline $06 / 6,7 / 04$ & Boggerik & Farmer fish (Stegastus sp) & 6 \\
\hline $06 / 6,7 / 04$ & Roi Namur & Farmer fish (Stegastus sp) & 5 \\
\hline
\end{tabular}

At LLNL, the marine fauna samples were thawed and rinsed to remove any adhering sand or other debris before being placed into clean photo trays for dissection. Muscle tissue was dissected from all species along with liver tissue from the larger fish and eels. Care was exercised to prevent cross -contamination between tissue types. The dissected material from each composite sample was diced, placed in plastic freezer containers and dried by lyophilization. The dried material was then reweighted to estimate the wet/dry ratio of tissue, and then homogenized in a laboratory blender 


\section{Collection and initial preparation of sediment (beach sand)}

Beach sands at Illeginni Island and Boggerik Islet were collected using plastic cups, the material placed in plastic bags, and shipped frozen to LLNL for analysis. NMF and NFWS personnel initially selected a series of sites along Illeginni for collecting beach-sand samples (red triangles in Fig. 1).

Additional sites along the ocean-side reef (black triangles in Fig.1) were selected by LLNL personnel to provide additional coverage of the down-wind, down-trajectory side of the island. The sample site coordinates for Illeginni Island are listed in Table 2. NMF and NFWS personnel were responsible for collecting beach sand at Boggerik Islet control site on both ocean and lagoon sides of the islet.

To prepare samples for chemical analysis, the bulk sediments were placed in metal cans and dried by lyophilization. Lids were placed on the cans and the dried material homogenized for 24-h by agitation on a rolling mill. Large shell fragments and pebbles were removed prior to sample analysis by sieving samples through a 16-mesh $(1.6 \mathrm{~mm}) \mathrm{NBS}$ screen.

\section{Chemical Processing}

Chemical analyses of marine fauna were performed on $10 \mathrm{~g}$ aliquots of dried material or as much material as available. The samples were initially weighted into $500 \mathrm{ml}$ glass beaker and dry ashed in an oven for 64 hours. The ashed residues was then transferred to acid leached polypropylene digestion vessels and dissolved by heating on a hotblock with addition of $40 \mathrm{~g}$ of a 1:1 mixture of concentrated nitric acid and 30\% hydrogen peroxide. Sample dissolution was continued with periodic additions of a few milliliters of hydrogen peroxide until the digest was clear and colorless.

Sediment samples were treated in a similar fashion using $1 \mathrm{~g}$ aliquots of sample matrix and addition of $20 \mathrm{~g}$ of the concentrated nitric acid and hydrogen peroxide mixture. Total dissolution of sediments was insured by dissolution of any residue in nitric-hydrofluoric acid. All samples were then evaporated to near-dryness, re-hydrated in $2 \%$ ultrapure nitric acid, and filtered through a $0.45 \mu \mathrm{m}$ syringe filter to constant volume. Appropriate gravimetric dilutions were then prepared for chemical analysis by serial dilution of the stock digest.

$\mathrm{Be})$ and $\mathrm{U}$ were measured by Inductively Coupled Plasma Mass Spectrometry (ICP-MS) with addition of 1 ppm of lithium-6 ( $\mathrm{Li}$ ) (for Be analysis) and $1 \mathrm{ppb}$ of uranium-233 $\left({ }^{233} \mathrm{U}\right.$ ) (for $\mathrm{U}$ analysis) as internal standards. Iron and calcium were analyzed separately using Inductively Coupled Plasma Atomic Emission Spectrometry (ICP-AES). Control samples included blanks and approximately $10 \%$ of blind replicates prepared from the stock digest. A series of MAPEP inter-comparison soils were also prepared and analyzed as quality control samples for the Be and $\mathrm{U}$ analyses (reported separately).

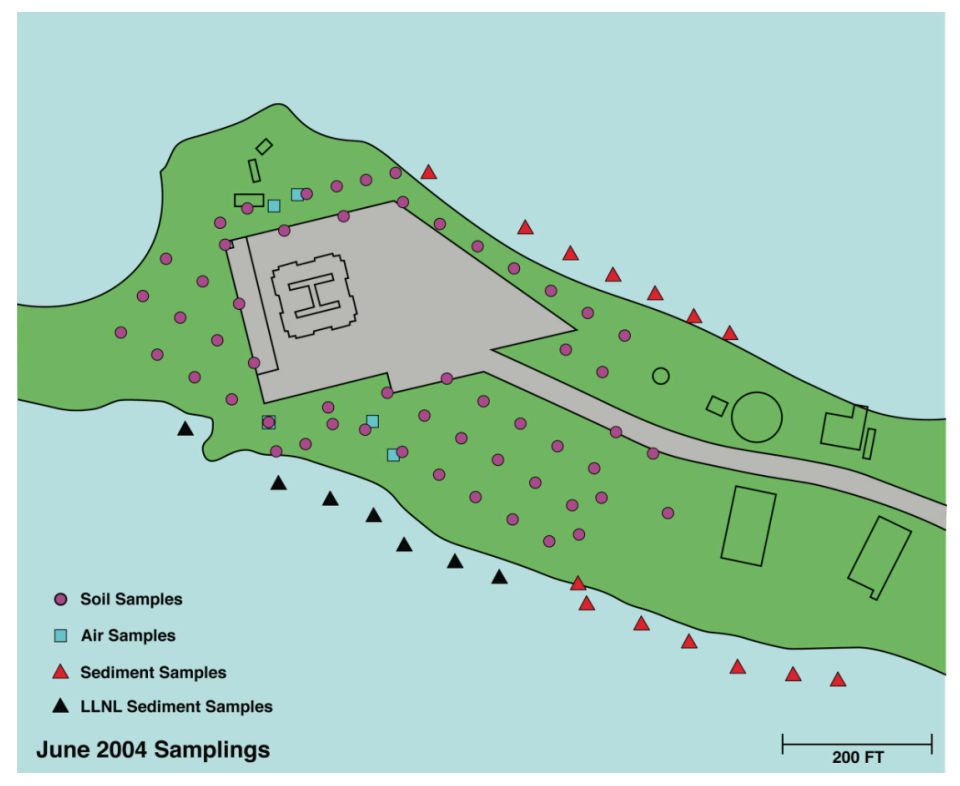

Fig.1 Marine sediment (beach sand) sample locations are identified by color triangles. Also on the figure are terrestrial soil sample sites and hi-volume air sampling locations. 
Table 2. Location and coordinates of marine sediment (beach sand) collected at Illeginni Island

\begin{tabular}{|c|c|c|c|}
\hline Date & Location & Latitude & Longitude \\
\hline 06/09/04 & Ocean side & $9^{0} 5^{\prime} 10.32^{\prime \prime}$ & $167^{0} 28^{\prime} 17.44^{\prime \prime}$ \\
\hline 06/09/04 & Ocean side & $9^{0} 5^{\prime} 10.40^{\prime \prime}$ & $167^{0} 28^{\prime} 16.84^{\prime \prime}$ \\
\hline 06/09/04 & Ocean side & $9^{0} 5^{\prime} 10.50^{\prime \prime}$ & $167^{0} 28^{\prime} 16.10^{\prime \prime}$ \\
\hline 06/09/04 & Ocean side & $9^{0} 5^{\prime} 10.84^{\prime \prime}$ & $167^{0} 28^{\prime} 15.44^{\prime \prime}$ \\
\hline 06/09/04 & Ocean side & $9^{0} 5^{\prime} 11.08^{\prime \prime}$ & $167^{0} 28^{\prime} 14.80^{\prime \prime}$ \\
\hline 06/09/04 & Ocean side & $9^{0} 5^{\prime} 11.35^{\prime \prime}$ & $167^{0} 28^{\prime} 14.05^{\prime \prime}$ \\
\hline 06/09/04 & Ocean side & $9^{0} 5^{\prime} 11.61^{\prime \prime}$ & $167^{0} 28^{\prime} 13.94^{\prime \prime}$ \\
\hline 06/09/04 & Ocean side & $9^{0} 5^{\prime} 13.69^{\prime \prime}$ & $167^{0} 28^{\prime} 8.67^{\prime \prime}$ \\
\hline 07/18/04 & Ocean side & $9^{0} 5^{\prime} 11.77^{\prime \prime}$ & $167^{0} 28^{\prime} 12.84^{\prime \prime}$ \\
\hline 07/18/04 & Ocean side & $9^{0} 5^{\prime} 12.00^{\prime \prime}$ & $167^{0} 28^{\prime} 12.25^{\prime \prime}$ \\
\hline $07 / 18 / 04$ & Ocean side & $9^{0} 5^{\prime} 12.28^{\prime \prime}$ & $167^{0} 28^{\prime} 11.64^{\prime \prime}$ \\
\hline 07/18/04 & Ocean side & $9^{0} 5^{\prime} 12.57^{\prime \prime}$ & $167^{0} 28^{\prime} 11.21^{\prime \prime}$ \\
\hline 07/18/04 & Ocean side & $9^{0} 5^{\prime} 12.75^{\prime \prime}$ & $167^{0} 28^{\prime} 10.59^{\prime \prime}$ \\
\hline 07/18/04 & Ocean side & $9^{0} 5^{\prime} 13.02^{\prime \prime}$ & $167^{0} 28^{\prime} 9.92^{\prime \prime}$ \\
\hline 06/09/04 & Lagoon side & $9^{0} 5^{\prime} 15.00^{\prime \prime}$ & $167^{0} 28^{\prime} 16.00^{\prime \prime}$ \\
\hline 06/09/04 & Lagoon side & $9^{0} 5^{\prime} 15.22^{\prime \prime}$ & $167^{0} 28^{\prime} 15.49^{\prime \prime}$ \\
\hline 06/09/04 & Lagoon side & $9^{0} 5^{\prime} 15.53^{\prime \prime}$ & $167^{0} 28^{\prime} 14.98^{\prime \prime}$ \\
\hline 06/09/04 & Lagoon side & $9^{0} 5^{\prime} 15.78^{\prime \prime}$ & $167^{0} 28^{\prime} 14.40^{\prime \prime}$ \\
\hline 06/09/04 & Lagoon side & $9^{0} 5^{\prime} 16.07^{\prime \prime}$ & $167^{0} 28^{\prime} 13.84^{\prime \prime}$ \\
\hline 06/09/04 & Lagoon side & $9^{0} 5^{\prime} 16.42^{\prime \prime}$ & $167^{0} 28^{\prime} 13.23^{\prime \prime}$ \\
\hline 06/09/04 & Lagoon side & $9^{0} 5^{\prime} 17.17^{\prime \prime}$ & $167^{0} 28^{\prime} 11.94^{\prime \prime}$ \\
\hline
\end{tabular}

\section{Statistical analysis of the data}

The Mann-Whitney U test (Siegel, 1956), a powerful non-parametric statistical test to determine if two independent sample sets were drawn from the same population, was used to evaluate marine fauna and sediment data sets. Non-parametric statistical tests are more powerful for cases where the number of samples in the set is small and the distribution is unknown. The Mann-Whitney U test is far more powerful than parametric tests such as the Student Ttest under such conditions. When the number of samples in one of the two sets of data exceeded 20, the Mann- Whitney U statistic was used to calculate the $\mathrm{Z}$ statistic (a parametric test) to determine the probability under the null hypothesis.

\section{Uranium Concentration in Coral soils}

Concentration of $\mathrm{U}$ in coral soil in the Marshall Islands is discussed in detail in Robison et al., 2001. A brief summary is given here with tables abstracted from Robison et al., 2001. The mean concentration of $U$ in several closed system corals (live functioning coral reefs) from around the world is $2.9 \mu \mathrm{g} \mathrm{g}^{-1}$ (Table 3). Uranium concentration decreases in open-system coral soils and beach sand (Thurber et al., 1965) as is evident in the results shown in Tables 4 through 7. Concentration of $U$ ranges between 1.6 to $2.0 \mu \mathrm{g} \mathrm{g}^{-1}$ for 3220 coral sands and soils measured in the northern Marshall Islands including results from the Republic of the Marshall Islands Nationwide Radiological Survey (RMI-NRS). Other results from the RMI-NRS show a mean value for $\mathrm{U}$ of $2.1 \mu \mathrm{g} \mathrm{g}^{-1}$ for atolls arbitrarily classed as mid-atolls (Table 7) although the mean value for Kwajalein was $1.7 \mu \mathrm{g} \mathrm{g}^{-1}$. The mean value for the southern atolls was a little higher again with a mean of $2.6 \mu \mathrm{g} \mathrm{g}^{-1}$. So, a mean $\mathrm{U}$ concentration of 1.6 to $2.0 \mu \mathrm{g} \mathrm{g}^{-1}$ in coral soil and beach sand is well established in the northern Marshall Islands and some of the more northern of the mid-atolls. 
Table 3. Concentration of $\mathrm{U}( \pm 1$ standard error) in corals from global locations

\begin{tabular}{lccl}
\hline \multicolumn{1}{c}{ Location } & $\begin{array}{c}\text { Number } \\
\text { of }^{\mathbf{2 3 8} \mathbf{U}} \\
\mathbf{s a m p l e s}\end{array}$ & $\begin{array}{c}\text { Mean } \\
\boldsymbol{\mu g ~ g}^{\mathbf{1}}\end{array}$ & \multicolumn{1}{c}{ Source } \\
\hline Enewetak & 36 & $2.9 \pm 0.1$ & Thurber et al., 1965 \\
Florida Keys & 15 & $2.7 \pm 0.1$ & Broecker \& Thurber, 1965 \\
Hawaii $^{\mathrm{a}}$ & 6 & $2.5 \pm 0.2$ & Veeh \& Turekian, 1968 \\
Samoa $^{\mathrm{b}}$ & 5 & $2.3 \pm 0.2$ & Veeh \& Turekian, 1968 \\
Tahiti $^{\mathrm{b}}$ & 5 & $2.1 \pm 0.1$ & Veeh \& Turekian, 1968 \\
Tuamotub & 8 & $1.8 \pm 0.1$ & Veeh \& Turekian, 1968 \\
Enewetak & 18 & $3.9 \pm 0.1$ & Barnes et al., 1956 \\
Florida Keys ${ }^{\mathrm{c}}$ & 2 & $2.9 \pm 0.4$ & Tatsumoto \& Goldberg, 1959 \\
\hline
\end{tabular}

a Three samples each of two genus of corals.

b Three samples of one genus of coral and two samples of another genus of coral

c Two genus of corals

Table 4. The concentration \pm 1 standard error of ${ }^{238} \mathrm{U}$ in coral soil from Majuro, Kwajalein, Wotje, Ponape, and Truk Atolls

\begin{tabular}{|c|c|c|c|}
\hline Location & $\begin{array}{c}\begin{array}{c}\text { Number } \\
\text { of } \\
\text { samples }\end{array} \\
\end{array}$ & $\begin{array}{l}\text { Mean } \\
\mu \mathrm{g} \mathrm{g}^{-1} \\
\end{array}$ & Source \\
\hline Majuro $^{a}$ & 8 & $2.2 \pm 0.3^{\mathrm{e}}$ & $\begin{array}{l}\text { University of Washington (UW), } \\
\text { Nelson }^{\mathrm{f}}, 1979 \mathrm{a}\end{array}$ \\
\hline Majuro $^{a}$ & 5 & $1.7 \pm 0.2$ & LLNL $^{\mathrm{g}}$, Robison et al., 2001 \\
\hline Majuro $^{b}$ & 40 & $1.7 \pm 0.1$ & LLNL $^{\mathrm{f}}$, Robison et al., 2001 \\
\hline Wotje $^{c}$ & 17 & $2.1 \pm 0.1$ & UW, Nelson ${ }^{\mathrm{f}}, 1979 \mathrm{~b}$ \\
\hline Kwajalein $^{\mathrm{d}}$ & 47 & $1.9 \pm 0.1$ & LLNL $^{\mathrm{g}}$, Robison et al., 2001 \\
\hline Ponape & 12 & $2.8 \pm 0.3$ & UW, Nelson ${ }^{\mathrm{f}}, 1979 \mathrm{a}$ \\
\hline Truk & 13 & $3.6 \pm 0.3$ & UW, Nelson ${ }^{\mathrm{f}}, 1979 \mathrm{a}$ \\
\hline All samples & 149 & $2.1 \pm 0.1$ & \\
\hline
\end{tabular}

\footnotetext{
Majuro to Laura.

Majuro, Enemanet, and Eneko Islands

Wormej and Wotje Islands.

Gagan, Gellinam, Roi Namur, and Illeginni Islands.

Standard error of the mean.

Data generated by gamma spectroscopy.

g Data generated by ICP mass spectrometry.
} 
Table 5. The concentration \pm 1 standard error of ${ }^{238} \mathrm{U}$ in soil and lagoon sediments at the northern Marshall Islands

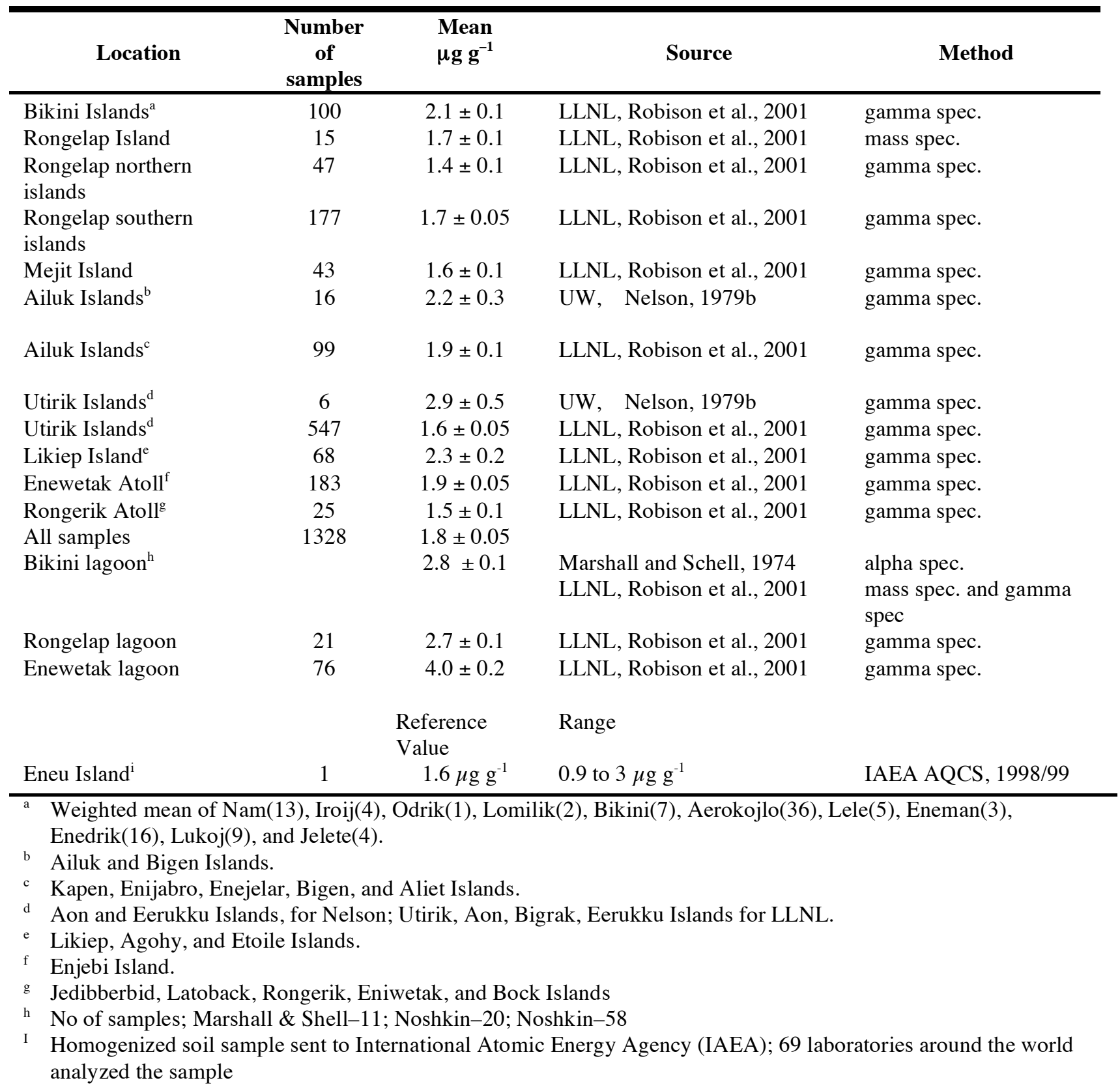


Table 6. The concentration \pm 1 standard error of ${ }^{238} \mathrm{U}$ in soil at Enewetak Atolla

\begin{tabular}{lcc}
\hline \multicolumn{1}{c}{ Location } & $\begin{array}{c}\text { Number } \\
\text { of } \\
\text { samples }\end{array}$ & $\begin{array}{c}\text { Mean } \\
\boldsymbol{\mu g ~ g}^{-\mathbf{1}}\end{array}$ \\
\hline Southern Islands & & \\
Anniji & 29 & $1.4 \pm 0.1$ \\
Japtan & 131 & $2.0 \pm 0.1$ \\
Medren & 304 & $1.7 \pm 0.1$ \\
Enewetak & 422 & $1.7 \pm 0.1$ \\
All samples & 886 & $1.8 \pm 0.05$ \\
& & \\
Northern and Eastern Islands & & $1.8 \pm 0.2$ \\
Aje & 15 & $1.4 \pm 0.1$ \\
Lujor & 45 & $1.8 \pm 0.2$ \\
Aomen & 25 & $1.5 \pm 0.1$ \\
Bijire & 46 & $1.6 \pm 0.1$ \\
Lojwa & 55 & $1.7 \pm 0.1$ \\
Alembel & 50 & $1.5 \pm 0.1$ \\
Runit & 70 & $1.9 \pm 0.1$ \\
Enjebi & 183 & $1.7 \pm 0.05$ \\
All samples & 489 & \\
\hline A from Robition
\end{tabular}

A from Robison et al., 2001

Table 7. Concentration ( \pm 1 standard error) of ${ }^{238} U$ in atoll soils in the Marshall Islands ${ }^{\text {a }}$

\begin{tabular}{|c|c|c|c|c|c|}
\hline Southern Atolls & $\begin{array}{l}\text { Mean } \\
\mu \mathrm{g} \mathrm{g}^{-1}\end{array}$ & $\begin{array}{l}\text { Mid- } \\
\text { Atolls }\end{array}$ & $\begin{array}{l}\text { Mean } \\
\mu \mathrm{g} \mathrm{g}^{-1}\end{array}$ & $\begin{array}{c}\text { Northern } \\
\text { Atolls }\end{array}$ & $\begin{array}{l}\text { Mean } \\
\mu \mathrm{g} \mathrm{g}^{-1}\end{array}$ \\
\hline Ailinglaplap $(24)^{\mathrm{b}}$ & $2.6 \pm 0.20$ & Aur (24) & $2.2 \pm 0.1$ & Ailinginae (54) & $1.6 \pm 0.1$ \\
\hline Ebon & $2.2 \pm 0.16$ & Kwajalein (54) & $1.7 \pm 0.1$ & Bikinu (340 & $1.8 \pm 0.1$ \\
\hline Arno (24) & $3.3 \pm 0.16$ & Erikub (12) & $1.6 \pm 0.1$ & Ailuk (18) & $1.9 \pm 0.1$ \\
\hline Jaluit (24) & $2.2 \pm 0.26$ & Lae (18) & $2.5 \pm 0.2$ & Enewetak (44) & $1.6 \pm 0.1$ \\
\hline Kili (6) & $3.0 \pm 0.31$ & Lib (12) & $2.4 \pm 0.1$ & Mejit (11) & $1.8 \pm 0.1$ \\
\hline Knox (6) & $2.5 \pm 0.31$ & Likiep (36) & $2.2 \pm 0.1$ & Rongelap (106) & $1.7 \pm 0.1$ \\
\hline Majuro (72) & $2.5 \pm 0.16$ & Maleolap (24) & $1.5 \pm 0.1$ & Rongerik (28) & $1.2 \pm 0.1$ \\
\hline Namorik (12) & $2.2 \pm 0.41$ & Namu (24) & $2.7 \pm 0.2$ & Taongi & $1.8 \pm 0.1$ \\
\hline Mili (24) & $2.5 \pm 0.16$ & Ujae (18) & $2.3 \pm 0.2$ & Taka (24) & $2.0 \pm 0.1$ \\
\hline Jabat (6) & $2.8 \pm 0.32$ & Ujelang (42) & $2.4 \pm 0.2$ & Utirik (25) & $1.8 \pm 0.1$ \\
\hline \multirow[t]{2}{*}{. } & & Wotho (18) & $1.9 \pm 0.1$ & Jemo (6) & $2.2 \pm 0.3$ \\
\hline & & Wotje (24) & $1.9 \pm 0.1$ & & \\
\hline Total (216) & $2.6 \pm 0.08$ & Total (306) & $2.1 \pm 0.05$ & Total (368) & $1.7 \pm 0.05$ \\
\hline
\end{tabular}

a Data from the RMI Nationwide Radiological Survey conducted by Dr. Steve Simont ${ }^{1}$ (see Robison et al., 2001)

b Number of samples are in parentheses.

${ }^{1}$ Dr. Steven L. Simon, National Cancer Institute, 6120 Executive Blvd., MSC7238, Executive Plaza South, Betheda, MD 20892-7238 


\section{Results}

Results of analysis of $U$ and Be are listed in Table 8 for marine fauna collected at Illeginni and Boggerik Islands. Concentrations are listed as $\mathrm{ng} \mathrm{g}^{-1}$ and include means, medians, and standard deviations. Mean U concentration and associated standard deviation for all samples at Illeginni Island is $9.8 \pm 5.3 \mathrm{ng} \mathrm{g}^{-1}$ and is $9.0 \pm 8.0 \mathrm{ng} \mathrm{g}^{-1}$ for Boggerik
Island. Mean Be concentration and standard deviation for Illeginni and Boggerik is $1.5 \pm 2.7 \mathrm{ng} \mathrm{g}^{-1}$ and $1.7 \pm$ $2.2 \mathrm{ng} \mathrm{g}^{-1}$, respectively. There is no statistically significant difference in the concentration of $\mathrm{Be}(\mathrm{p} \geq$ $0.34)$ and $U(p \geq 0.14)$ between Illeginni Island fauna samples and Boggerik Island control site fauna samples.

Table 8 . Be and $U$ concentration in all marine fauna at Illeginni and Boggerik Islands

\begin{tabular}{|c|c|c|c|c|c|c|c|c|c|}
\hline Date & Location & Species & $\begin{array}{c}\mathrm{U} \\
\mathrm{ng} \mathrm{g}^{-1} \\
\end{array}$ & $\begin{array}{c}\text { Be } \\
\operatorname{ng~g~}^{-1} \\
\end{array}$ & Date & Location & Species & $\begin{array}{c}\mathrm{U} \\
\mathrm{ng} \mathrm{g}^{-1}\end{array}$ & $\begin{array}{c}\text { Be } \\
\text { ng g }^{-1}\end{array}$ \\
\hline \multicolumn{5}{|c|}{ Illeginni Island } & \multicolumn{5}{|c|}{ Boggeriik Island, Control Site } \\
\hline 06/08/04 & Ocean & Snowflake eel liver & 12 & -0.34 & $06 / 6,7 / 04$ & Boggerik & Moray eel muscle & 0.9 & 0.77 \\
\hline 06/08/04 & Ocean & Snowflake eel muscle & 4.2 & -0.43 & $06 / 6,7 / 04$ & Boggerik & Moray eel liver & 8.3 & 1.3 \\
\hline 06/09/04 & Lagoon & Rock crab & 6.8 & 7.2 & $06 / 6,7 / 04$ & Boggerik & $\begin{array}{l}\text { Snowflake eels } \\
\text { muscle } \\
\text { Snowflake eels }\end{array}$ & 17 & 4.7 \\
\hline 06/09/04 & Lagoon & Snowflake eel liver & 15 & -0.085 & $06 / 6,7 / 04$ & Boggerik & liver & 21 & 0.024 \\
\hline 06/09/04 & Lagoon & Snowflake eel muscle & 11 & -0.70 & $06 / 6,7 / 04$ & Boggerik & $\begin{array}{l}\text { Snowflake eels } \\
\text { muscle } \\
\text { Snowflake eels }\end{array}$ & 4.1 & -0.17 \\
\hline 06/09/04 & Ocean & Black-tip shark liver & 11 & 0.33 & $06 / 6,7 / 04$ & Boggerik & liver & 24 & -0.37 \\
\hline 06/09/04 & Ocean & Rock crab & 4.2 & 7.7 & $06 / 6,7 / 04$ & Boggerik & Rock crab & 3.1 & 4.8 \\
\hline 06/09/04 & Ocean & Rock crab & 5.4 & 5.6 & $06 / 6,7 / 04$ & Boggerik & Rock crab & 6.0 & 4.3 \\
\hline 06/09/04 & Ocean & Snowflake eel liver & 9.9 & 0.039 & $06 / 6,7 / 04$ & Boggerik & Rock crab & 4.0 & 3.8 \\
\hline 06/09/04 & Ocean & Snowflake eel muscle & 9.7 & 5.6 & $06 / 6,7 / 04$ & Boggerik & Farmer fish & 8.1 & -0.23 \\
\hline 06/09/04 & Ocean & White-tip shark liver & 5.7 & -0.036 & $06 / 6,7 / 04$ & Roi Namur & Farmer fish & 2.3 & -0.24 \\
\hline $06 / 10 / 04$ & Lagoon & Farmer fish & 3.4 & 1.2 & & & Mean & 9.0 & 1.7 \\
\hline 06/10/04 & Lagoon & Rock crab & 11 & 1.2 & & & Stdev & 8.0 & 2.2 \\
\hline $06 / 10 / 04$ & Lagoon & Snowflake eel muscle & 14 & -6.9 & & & Median & 6.0 & 0.77 \\
\hline 06/10/04 & Lagoon & Snowflake eel liver & 18 & -0.28 & & & No. & 11 & 11 \\
\hline 06/10/04 & Lagoon & Snowflake eel muscle & 4.0 & 0.77 & & & & & \\
\hline $06 / 10 / 04$ & Lagoon & Snowflake eel liver & 14 & 0.40 & & & & & \\
\hline 06/10/04 & Lagoon & Snowflake eel liver & 24 & -0.19 & & & & & \\
\hline $06 / 10 / 04$ & Ocean & Snowflake eel liver & 4.0 & -0.34 & & & & & \\
\hline 06/10/04 & Ocean & Snowflake eel muscle & 10 & 3.2 & & & & & \\
\hline \multirow[t]{5}{*}{$06 / 10 / 04$} & Ocean & Snowflake eel muscle & 7.9 & 2.2 & & & & & \\
\hline & & Mean & 9.8 & 1.5 & & & & & \\
\hline & & Stdev & 5.3 & 2.7 & & & & & \\
\hline & & Median & 10 & 0.33 & & & & & \\
\hline & & No. & 21 & 21 & & & & & \\
\hline
\end{tabular}


Results of $\mathrm{U}$ and Be analysis for samples of marine sediment (beach sand) are listed in Table 9. Mean concentration at Illeginni Island for $\mathrm{U}$ is1.6 \pm $0.41 \mu \mathrm{g} \mathrm{g}^{-1}$ which is the same as the concentration observed throughout the Marshall Islands. Mean U concentration for Boggerik Island is $0.63 \pm 0.15 \mu \mathrm{g} \mathrm{g}^{-1}$. This low concentration of $U$ in beach-sand samples collected at Boggerik is due to the origin of the samples. They were distinctly different in color and size than coral sands from Illeginni because they contained a high percentage of mollusc shells rather than sand of coral origin. More detail is given in the Discussion section.

Mean concentration of Be at Illeginni is 0.027 $\pm 0.11 \mu \mathrm{g} \mathrm{g}^{-1}$ while it is $-0.00056 \mu \mathrm{g} \mathrm{g}^{-1} \pm 0.0042 \mu \mathrm{g} \mathrm{g}^{-1}$, (essentially undetectable at the detection limit) at Boggerik. Mean concentration of $27 \mathrm{ng} \mathrm{g}^{-1}$ (27 parts per billion) for $\mathrm{Be}$ in marine sediment is slightly higher at Illeginni where Be was detected at very low concentrations in only 6 out of 21 samples while being undetectable in all Boggerik Island samples. They test significantly different at $\mathrm{p}=0.018$.

Table 9. Be and $U$ in marine sediment (beach sand) at Illeginni and Boggerik Islands

\begin{tabular}{|c|c|c|c|c|c|c|c|c|}
\hline Date & Side & $\begin{array}{c}\text { Sample } \\
\text { no. }\end{array}$ & $\begin{array}{c}\mathrm{U} \\
\mu \mathrm{g} \mathrm{g}^{-1}\end{array}$ & $\begin{array}{c}\mathrm{Be} \\
\mu \mathrm{g} \mathrm{g}^{-1}\end{array}$ & Date & Side & $\begin{array}{c}\mathrm{U} \\
\mu \mathrm{g} \mathrm{g}^{-1}\end{array}$ & $\begin{array}{c}\mathrm{Be} \\
\mu \mathrm{g} \mathrm{g}^{-1}\end{array}$ \\
\hline Illeginni Island & & & \multicolumn{6}{|c|}{ Boggerik Island, Control Site } \\
\hline 06/09/04 & Ocean & 1 & 1.7 & -0.0086 & $06 / 6,7 / 04$ & Ocean & 0.48 & -0.0043 \\
\hline 06/09/04 & Ocean & 2 & 1.3 & -0.0075 & $06 / 6,7 / 04$ & Ocean & 0.57 & -0.0060 \\
\hline 06/09/04 & Ocean & 3 & 1.1 & -0.0073 & $06 / 6,7 / 04$ & Ocean & 0.38 & -0.0073 \\
\hline 06/09/04 & Ocean & 4 & 1.4 & -0.0070 & $06 / 6,7 / 04$ & Ocean & 0.61 & -0.0057 \\
\hline 06/09/04 & Ocean & 5 & 1.3 & -0.0089 & $06 / 6,7 / 04$ & Ocean & 0.71 & -0.0070 \\
\hline 06/09/04 & Ocean & 6 & 1.4 & -0.0086 & $06 / 6,7 / 04$ & Ocean & 0.40 & -0.0070 \\
\hline 06/09/04 & Ocean & 7 & 1.5 & 0.0044 & $06 / 6,7 / 04$ & Lagoon & 0.66 & -0.0072 \\
\hline 07/18/04 & Ocean & 8 & 3.1 & 0.48 & 06/6,7/04 & Lagoon & 0.76 & -0.0070 \\
\hline $07 / 18 / 04$ & Ocean & A & 1.6 & -0.0044 & $06 / 6,7 / 04$ & Lagoon & 0.60 & -0.0066 \\
\hline $07 / 18 / 04$ & Ocean & B & 1.5 & 0.0030 & $06 / 6,7 / 04$ & Lagoon & 0.75 & -0.0071 \\
\hline 07/18/04 & Ocean & $\mathrm{C}$ & 1.6 & 0.0073 & $06 / 6,7 / 04$ & Lagoon & 0.91 & -0.0074 \\
\hline $07 / 18 / 04$ & Ocean & D & 1.6 & 0.0072 & $06 / 6,7 / 04$ & Lagoon & 0.68 & -0.0090 \\
\hline $07 / 18 / 04$ & Ocean & E & 1.4 & 0.017 & & Mean & 0.63 & -0.0056 \\
\hline 06/09/04 & Ocean & $\mathrm{F}$ & 2.0 & 0.14 & & Stdev & 0.15 & 0.0042 \\
\hline 06/09/04 & Lagoon & 1 & 1.7 & -0.0083 & & Median & 0.64 & -0.0070 \\
\hline 06/09/04 & Lagoon & 2 & 1.4 & 0 & & No. & 12 & 12 \\
\hline 06/09/04 & Lagoon & 3 & 1.4 & -0.0043 & & & & \\
\hline 06/09/04 & Lagoon & 4 & 1.5 & -0.0042 & & & & \\
\hline 06/09/04 & Lagoon & 5 & 1.3 & -0.0056 & & & & \\
\hline \multirow[t]{6}{*}{ 06/09/04 } & Lagoon & 6 & 1.4 & -0.0030 & & & & \\
\hline & Lagoon & 7 & 1.4 & -0.0038 & & & & \\
\hline & & Mean & 1.6 & 0.027 & & & & \\
\hline & & Stdev & 0.41 & 0.11 & & & & \\
\hline & & Median & 1.4 & -0.0042 & & & & \\
\hline & & No. & 21 & 21 & & & & \\
\hline
\end{tabular}


Concentration of $\mathrm{Fe}$ and $\mathrm{Ca}$ in marine sediments is listed in Table 10. The mean concentration of $\mathrm{Fe}$ in marine sediment from Boggerik Island is $0.0031 \pm 0.00075 \mathrm{mg} \mathrm{g}^{-1}$ and from Illeginni Island $1.2 \pm$ $1.6 \mathrm{mg} \mathrm{g}^{-1}$. Iron was found in sediment samples from both the lagoon and ocean sides of Illeginni Island and the concentrations are greater by about a factor of 400 than those at Boggerik Island. Calcium mean concentration in all sediment samples was about $340 \mathrm{mg}$ $\mathrm{g}^{-1}$, or $34 \%$, indicating $\mathrm{CaCO}_{3}$ sediment of marine origin.

Table 10. Fe and Ca concentration in marine sediment at Illeginni and Boggerik Islands

\begin{tabular}{|c|c|c|c|c|c|c|c|c|}
\hline Date & Side & $\begin{array}{l}\text { Sample } \\
\text { no. }\end{array}$ & $\begin{array}{c}\mathrm{Fe} \\
\mathrm{mg} \mathrm{g}^{-1}\end{array}$ & $\begin{array}{c}\mathrm{Ca} \\
\mathrm{mg} \mathrm{g}^{-1}\end{array}$ & Date & Side & $\begin{array}{c}\text { Fe } \\
\text { mg g }^{-1}\end{array}$ & $\begin{array}{c}\mathrm{Ca} \\
\mathrm{mg} \mathrm{g}^{-1}\end{array}$ \\
\hline \multicolumn{5}{|c|}{$\begin{array}{l}\text { Illeginni Island } \\
\text { Beach sand }\end{array}$} & \multicolumn{4}{|c|}{$\begin{array}{l}\text { Boggerik Island, Control Site } \\
\text { Beach Sand }\end{array}$} \\
\hline 06/09/04 & Ocean & 1 & 0.016 & 338 & $06 / 6,7 / 04$ & Ocean & 0.0030 & 333 \\
\hline 06/09/04 & Ocean & 2 & 0.0083 & 334 & $06 / 6,7 / 04$ & Ocean & 0.0025 & 333 \\
\hline 06/09/04 & Ocean & 3 & 0.009 & 325 & $06 / 6,7 / 04$ & Ocean & 0.0035 & 328 \\
\hline 06/09/04 & Ocean & 4 & 0.067 & 323 & $06 / 6,7 / 04$ & Ocean & 0.0029 & 336 \\
\hline 06/09/04 & Ocean & 5 & 0.15 & 358 & 06/6,7/04 & Ocean & 0.0022 & 362 \\
\hline 06/09/04 & Ocean & 6 & 0.054 & 373 & $06 / 6,7 / 04$ & Ocean & 0.0042 & 351 \\
\hline 06/09/04 & Ocean & 7 & 0.72 & 336 & $06 / 6,7 / 04$ & Lagoon & 0.0036 & 318 \\
\hline 06/09/04 & Ocean & 8 & 4.6 & 331 & $06 / 6,7 / 04$ & Lagoon & 0.0027 & 360 \\
\hline $07 / 18 / 04$ & Ocean & A & 0.44 & 357 & $06 / 6,7 / 04$ & Lagoon & 0.0023 & 317 \\
\hline $07 / 18 / 04$ & Ocean & B & 1.2 & 332 & $06 / 6,7 / 04$ & Lagoon & 0.0029 & 321 \\
\hline 07/18/04 & Ocean & $\mathrm{C}$ & 0.17 & 327 & 06/6,7/04 & Lagoon & 0.0031 & 331 \\
\hline $07 / 18 / 04$ & Ocean & $\mathrm{D}$ & 0.38 & 331 & $06 / 6,7 / 04$ & Lagoon & 0.0047 & 336 \\
\hline $07 / 18 / 04$ & Ocean & $\mathrm{E}$ & 0.70 & 353 & & Mean & 0.0031 & 335 \\
\hline $07 / 18 / 04$ & Ocean & $\mathrm{F}$ & 3.0 & 363 & & Stdev & 0.00075 & 15 \\
\hline 06/09/04 & Lagoon & 1 & 0.73 & 315 & & Median & 0.0030 & 333 \\
\hline 06/09/04 & Lagoon & 2 & 5.9 & 338 & & No. & 12 & 12 \\
\hline 06/09/04 & Lagoon & 3 & 1.6 & 332 & & & & \\
\hline 06/09/04 & Lagoon & 4 & 2.3 & 331 & & & & \\
\hline 06/09/04 & Lagoon & 5 & 0.58 & 369 & & & & \\
\hline 06/09/04 & Lagoon & 6 & 0.87 & 344 & & & & \\
\hline \multirow[t]{5}{*}{ 06/09/04 } & Lagoon & 7 & 0.37 & 382 & & & & \\
\hline & & Mean & 1.2 & 340 & & & & \\
\hline & & Stdev & 1.6 & 18 & & & & \\
\hline & & Median & 0.57 & 336 & & & & \\
\hline & & No. & 21 & 21 & & & & \\
\hline
\end{tabular}


Table 11 contains results of Fe analysis of marine fauna liver and muscle at Illeginni and Boggerik Islands. Mean concentration of $\mathrm{Fe}$ in liver samples is $3.4 \pm 3.5 \mathrm{mg} \mathrm{g}^{-1}$ for Illeginni and $2.1 \pm 2.4 \mathrm{mg} \mathrm{g}^{-1}$. There is no statistically significant difference $(p \geq 0.10)$ between the two sites. The concentration in muscle tissue is a different story. For Illeginni and Boggerik Islands the mean concentration of Fe is $0.040 \pm 0.052 \mathrm{mg} \mathrm{g}^{-1}$ and $0.011 \pm 0,0045 \mathrm{mg} \mathrm{g}^{-1}$, respectively. The means are statistically different at $\mathrm{p}=0.001$.
There are two very high concentrations of $\mathrm{Fe}$ in muscle tissue of rock crabs at Illeginni ( 0.14 and 0.16 , bold in the table). These are the result of crabs living and crawling around in reef areas that have legacy scrap iron distributed over extensive areas. These two unusually high concentrations could perhaps drive the statistical difference between Illeginni and Boggerik. This possibility is tested in the data in Table 12

Table 11. Fe concentration in muscle and liver of marine fauna

\begin{tabular}{|c|c|c|c|c|c|c|c|c|}
\hline Date & Side & Species & $\begin{array}{l}\mathrm{Fe} \\
\mathrm{mg} \mathrm{g}^{-1}\end{array}$ & Date & Side & Species & $\begin{array}{l}\mathrm{Fe} \\
\mathrm{mg} \mathrm{g}^{-1}\end{array}$ & $\begin{array}{l}\mathrm{Fe} \\
\mu \mathrm{g} \mathrm{g}^{-1}\end{array}$ \\
\hline \multicolumn{4}{|c|}{ Illeginni Island liver data } & \multicolumn{5}{|c|}{ Illeginni Island muscle data } \\
\hline 06/08/04 & Ocean & Snowflake eel liver & 1.6 & 06/08/04 & Ocean & Snowflake eel muscle & 0.023 & 23 \\
\hline 06/09/04 & Lagoon & Snowflake eel liver & 2.0 & 06/09/04 & Lagoon & Rock crab & 0.016 & 16 \\
\hline 06/09/04 & Ocean & Black-tip shark liver & 1.3 & 06/09/04 & Lagoon & Snowflake eel muscle & 0.022 & 22 \\
\hline 06/09/04 & Ocean & Snowflake eel liver & 2.8 & $06 / 09 / 04$ & Ocean & Rock crab & 0.14 & 140 \\
\hline 06/09/04 & Ocean & White-tip shark liver & 0.35 & $06 / 09 / 04$ & Ocean & Rock crab & 0.16 & 160 \\
\hline 06/10/04 & Lagoon & Snowflake eel liver & 9.0 & 06/09/04 & Ocean & Snowflake eel muscle & 0.017 & 17 \\
\hline 06/10/04 & Lagoon & Snowflake eel liver & 9.9 & 06/10/04 & Lagoon & Farmer fish & 0.024 & 24 \\
\hline 06/10/04 & Lagoon & Snowflake eel liver & 2.6 & 06/10/04 & Lagoon & Rock crab & 0.012 & 12 \\
\hline \multirow[t]{8}{*}{ 06/10/04 } & Ocean & Snowflake eel liver & 1.1 & 06/10/04 & Lagoon & Snowflake eel muscle & 0.012 & 12 \\
\hline & & Mean & 3.4 & 06/10/04 & Lagoon & Snowflake eel muscle & 0.019 & 19 \\
\hline & & Stdev 1 & 3.5 & 06/10/04 & Lagoon & Snowflake eel muscle & 0.023 & 23 \\
\hline & & Median & 2.0 & $06 / 10 / 04$ & Ocean & Snowflake eel muscle & 0.016 & 16 \\
\hline & & No. & 9 & & & Mean & 0.040 & 40 \\
\hline & & & & & & Stdev. & 0.052 & 52 \\
\hline & & & & & & Median & 0.021 & 21 \\
\hline & & & & & & No. & 12 & 12 \\
\hline \multicolumn{4}{|c|}{ Boggerik Island, control site liver data } & \multicolumn{5}{|c|}{ Boggerik Island, control site muscle data } \\
\hline $06 / 6,7 / 04$ & Boggerik & Moray eel liver & 4.8 & $06 / 6,7 / 04$ & Boggerik & $\begin{array}{l}\text { Moray eel muscle } \\
\text { Snowflake eels }\end{array}$ & 0.0037 & 3.7 \\
\hline $06 / 6,7 / 04$ & Boggerik & Snowflake eels liver & 1.1 & $06 / 6,7 / 04$ & Boggerik & $\begin{array}{l}\text { muscle } \\
\text { Snowflake eels }\end{array}$ & 0.015 & 15 \\
\hline \multirow[t]{10}{*}{$06 / 6,7 / 04$} & Boggerik & Snowflake eels liver & 0.41 & $06 / 6,7 / 04$ & Boggerik & muscle & 0.009 & 9 \\
\hline & & Mean & 2.1 & $06 / 6,7 / 04$ & Boggerik & Rock crab & 0.010 & 10 \\
\hline & & Stdev. & 2.4 & $06 / 6,7 / 04$ & Boggerik & Rock crab & 0.013 & 13 \\
\hline & & Median & 1.1 & $06 / 6,7 / 04$ & Boggerik & Rock crab & 0.0071 & 7.1 \\
\hline & & No. & 3 & $06 / 6,7 / 04$ & $\begin{array}{l}\text { Boggerik } \\
\text { Roi }\end{array}$ & Farmer fish & 0.011 & 11 \\
\hline & & & & $06 / 6,7 / 04$ & Namur & Farmer fish & 0.018 & 18 \\
\hline & & & & & & Mean & 0.011 & 11 \\
\hline & & & & & & Stdev. & 0.0045 & 4.5 \\
\hline & & & & & & Median & 0.011 & 11 \\
\hline & & & & & & No. & 8 & 8 \\
\hline
\end{tabular}


Table 12 contains results of $\mathrm{Fe}$ analysis of marine fauna muscle at Illeginni and Boggerik Islands (control site) with the two very high values for rock crabs deleted from the Illeginni data set. In this case, the mean $\mathrm{Fe}$ concentration in muscle samples from Illeginni and Boggerik is $0.018 \pm 0.0045 \mathrm{mg} \mathrm{g}^{-1}$ and $0.011 \pm$ $0.0045 \mathrm{mg} \mathrm{g}^{-1}$, respectively. The results still test significantly different $(\mathrm{p}=0.001)$.

Table 12. Concentration of Fe in muscle of marine fauna (rock crabs deleted)

\begin{tabular}{|c|c|c|c|c|}
\hline Date & Side & Species & $\begin{array}{c}\text { Fe } \\
\mathrm{mg} \mathrm{g}^{-1}\end{array}$ & $\begin{array}{c}\mathrm{Fe} \\
\mu \mathrm{g} \mathrm{g}^{-1}\end{array}$ \\
\hline \multicolumn{5}{|c|}{ Illeginni Island muscle data Side } \\
\hline 06/08/04 & Ocean & Snowflake eel muscle & 0.023 & 23 \\
\hline 06/09/04 & Lagoon & Rock crab & 0.016 & 16 \\
\hline 06/09/04 & Lagoon & Snowflake eel muscle & 0.022 & 22 \\
\hline 06/09/04 & Ocean & Snowflake eel muscle & 0.017 & 17 \\
\hline 06/10/04 & Lagoon & Farmer fish & 0.024 & 24 \\
\hline 06/10/04 & Lagoon & Rock crab & 0.012 & 12 \\
\hline 06/10/04 & Lagoon & Snowflake eel muscle & 0.012 & 12 \\
\hline 06/10/04 & Lagoon & Snowflake eel muscle & 0.019 & 19 \\
\hline 06/10/04 & Lagoon & Snowflake eel muscle & 0.023 & 23 \\
\hline \multirow[t]{5}{*}{ 06/10/04 } & Ocean & Snowflake eel muscle & 0.016 & 16 \\
\hline & & Mean & 0.018 & 18 \\
\hline & & Stdev & 0.0045 & 4.5 \\
\hline & & Median & 0.018 & 18 \\
\hline & & No. & 10 & 10 \\
\hline \multicolumn{5}{|c|}{ Boggerik Island, muscle data } \\
\hline $06 / 6,7 / 04$ & Boggerik & Moray eel muscle & 0.0037 & 3.7 \\
\hline $06 / 6,7 / 04$ & Boggerik & Snowflake eel muscle & 0.015 & 15 \\
\hline $06 / 6,7 / 04$ & Boggerik & Snowflake eel muscle & 0.009 & 9 \\
\hline $06 / 6,7 / 04$ & Boggerik & Rock crab & 0.010 & 10 \\
\hline $06 / 6,7 / 04$ & Boggerik & Rock crab & 0.013 & 13 \\
\hline $06 / 6,7 / 04$ & Boggerik & Rock crab & 0.0071 & 7.1 \\
\hline $06 / 6,7 / 04$ & Boggerik & Farmer fish & 0.011 & 11 \\
\hline \multirow[t]{5}{*}{ 06/6,7/04 } & Roi Namur & Farmer fish & 0.018 & 18 \\
\hline & & Mean & 0.011 & 11 \\
\hline & & Stdev. & 0.0045 & 4.5 \\
\hline & & Median & 0.011 & 11 \\
\hline & & No. & 8 & 8 \\
\hline
\end{tabular}




\section{Discussion}

The fact that there is no increase in concentration of either $\mathrm{U}$ or $\mathrm{Be}$ in marine fauna is not unexpected because both of these elements are insoluble in the chemical form in which they exist in the re-entry vehicle. Even if they were soluble the mixing with the ocean as a result of ocean current flow (even as low as a centimeter per second) would lead to concentrations orders of magnitude below the natural concentration of these elements in sea water (McCright, 1996). Consequently, one would not expect to find any increase in $U$ and Be concentration in reef or pelagic fish, eels, turtles, filter feeders or other marine fauna as was indeed the case.

Concentration of $\mathrm{U}$ in beach sand collected from Illeginni Island is the same as that found in soil and beach sand throughout the Marshall Islands. Thus, there is no indication of increased $U$ in beach sand at Illeginni Island. Uranium concentration in beach sand from Boggerik Island (control site) was about half (mean $=0.63 \mu \mathrm{g} \mathrm{g}^{-1}$ ) of that in the Kwajalein beach sand $\left(\right.$ mean $\left.=1.6 \mu \mathrm{g} \mathrm{g}^{-1}\right)$. The lower concentration of $\mathrm{U}$ at Boggerik results from a difference in origin of its sediment (sands) from those of Illeginni. Beach sand samples from Illeginni are typical of sand of coral origin. They have fine texture, are relatively uniform in size, and are light tan to white in color. The Boggerik sand samples, on the other hand, have a coarse texture, a large range of particle size, contain lots of mollusc shells, and are pink in color. It is well known by marine geochemists that mollusc shells are low in $\mathrm{U}$ concentration and rarely exceed $0.5 \mu \mathrm{g} \mathrm{g}^{-1}$ (Veeh and Burnett, 1982) in the first 20 to $50 \mathrm{y}$ after deposition. The lower concentration observed in the Boggerik beach sand is a direct result of the fact they consist mostly of mollusc shells rather than sands of coral origin. There are many instances in the Marshall Islands where ocean circulation and deposition patterns are such that there is a high deposition of mollusc shells on beaches relative to coral sand. In these cases it would be expected to find a lower concentration of $U$ in the sample relative to a beach sand totally of coral origin.

Beach sands at Illeginni Island have a concentration of $\mathrm{Fe}$ that is about a factor of 400 greater than those from Boggerik Island. Concentration of Fe in sea water in areas where marine fauna were collected must also be much higher at Illeginni because mean $\mathrm{Fe}$ concentration in muscle tissue from marine fauna was higher by a factor of 4 at Illeginni relative to Boggerik
(0.004 $\mathrm{mg} \mathrm{g}^{-1}$ versus $0.011 \mathrm{mgmg}^{-1}$, respectively). This difference was not observed in liver samples because liver tissue naturally concentrates large quantities of $\mathrm{Fe}$ that effectively mask the smaller increase due to increased concentrations of $\mathrm{Fe}$ in the water.

\section{Conclusions}

Based on analysis of marine fauna described in this paper there is no difference between $\mathrm{U}$ and $\mathrm{Be}$ concentrations at Illeginni Island and the control site, Boggerik Island. Thus, there is no evidence that there has been any increase in $\mathrm{U}$ and Be concentrations in marine fauna as a result of the missile flight test program.

Concentration of $U$ in coral beach sand at Illeginni is the same as soil and coral beach sand in the rest of the Marshall Islands and again reflects an insignificant impact from the flight test program.

Beach sand from Illeginni has a mean concentration of Be higher than that from Boggerik Island. Seven of 21 samples from Ileginni had detectable Be. Four samples had a concentration of Be ranging from 4 to $7 \mathrm{ng} \mathrm{g}^{-1}$ [4 to 7 parts per billion (ppb)], one was $17 \mathrm{ppb}$, one was 0.14 parts per million (ppm) and one was $0.48 \mathrm{ppm}$. These extremely low concentrations of an insoluble form of Be again indicate no impact on marine life or human health at Illeginni as a result of the missile flight test program.

Concentration of $\mathrm{Fe}$ in marine fauna muscle tissue is much higher at Illeginni Island than at Boggerik Island (control site) as a result of legacy iron piers, dump sites for iron metal along the island, and scrap iron randomly distributed along extensive portions of the reef line as part of programs conducted in the 1960's through1980's that were not part of the recent flight test program.

\section{Acknowledgement}

This work was performed under the auspices of the U.S. Department of Energy by the University of California, Lawrence Livermore National Laboratory under Contract No. W-7405-Eng-48.

\section{Units used}

1 part per thousand $(\mathrm{ppt})=1 \mathrm{mg} \mathrm{g}^{-1}=0.001 \mathrm{~g} \mathrm{~g}^{-1}$ 1 part per million $(\mathrm{ppm})=1 \mu \mathrm{g} \mathrm{g}^{-1}=0.000001 \mathrm{~g} \mathrm{~g}^{-1}$ 1 part per billion $(\mathrm{ppb})=1 \mathrm{ng} \mathrm{g}^{-1}=0.000000001 \mathrm{~g} \mathrm{~g}^{-1}$ 


\section{References} $175-176$.

Barnes, J. W., E. J. Lang, and H. A. Potratz (1956), "Ratio of Ionium to Uranium in coral Limestone,” Science 124:

Broecker, W. S. and D. L. Thurber (1965), "Uranium-Series Dating of Corals and Oolites from Bahaman and Florida Key Limestones," Science 149: 55-58.

Marshall, R. P. and W. R. Schell (1974), Distribution of Alpha-emitting Radionuclides in Sediments of Bikini Atoll Lagoon, University of Washington, College of Fisheries, Laboratory of Radiation Ecology, Seattle, WA, RLO2225-T18-12.

McCright, D., (1996), Corrosion of U in Sea Water. Lawrence Livermore National Laboratory, internal report,

Nelson, V. A. (1979a), Radiological Survey of Plants, Animals, and soil in Micronesia, University of Washington, College of Fisheries, laboratory of Radiation Ecology, Seattle, WA, NVO-269-35.

Nelson, V. A. (1979b), Radiological survey of Plants, Animals, and soil at Five Atolls in the Marshall Islands, University of Washington, College of Fisheries, Laboratory of Radiation Ecology, NVO-269-36.

Robison, W. L. and J. H. Shinn, Environmental Assessment (1988), Re-Entry Vehicle Impact Dispersing Beryllium and Depleted uranium, Illeginni Island, Government of the Republic of the Marshall Islands. Lawrence Livermore National Laboratory report, UCAR-10260, Distribution limited.

Robison, W. L. and J. H. Shinn, (1990), The Concentrations of Be and DU in the air and soil at Illeginni Island after completion of the JTA-301 Mission. Lawrence Livermore National Laboratory report, UCRL-AR-104919, Controlled Distribution, OUO.

Robison, W. L. and R. Cederwall, (1992), Environmental Assessment; DOE Reentry Vehicles, Flight Test Program United States Army Kwajalein Atoll Republic of the Marshall Islands, Lawrence Livermore National Laboratory report.

Robison, W. L., (1992), The Distribution and Resuspension of Be and U at Kwajalein Atoll Subsequent to the GT10 and GT149 Missions in September 1992. Lawrence Livermore National Laboratory report, UCRL-ID-119110. Controlled Distribution.

Robison, W. L., V. E. Noshkin, T. F. Hamilton, C. L. Conrado, and K. T. Bogen (2001), An Assessment of the Current Day Impact of Various Materials Associated with the U. S. Nuclear Test Program in the Marshall Islands, Lawrence Livermore National Laboratory, Livermore, Ca, UCRL-LR-143980.

Siegel, S. (1956), Non-parametric Statistics, McGraw-Hill Book Company Inc. New York.

Tatsumoto, M. and E. D. Goldberg (1959), "Some Aspects of the Marine Geochemistry of Uranium," Geochimica et Cosmochimica Acta 17: 201-208.

Thurber, D. L., W. S. Broeker, R. L. Blanchard, and H. A. Potratz (1965), "Uranium-Series Ages of Pacific Atoll Coral," Science 149: 55-58.

Veeh, H. H. and K.K. Turekian (1968), "Cobolt, Silver, and Uranium Concentrations of Reef-Building Corals in the Pacific Ocean," Limno. Oceano. 13: 304-308.

Veeh, H. H. and W. C. Burnett, (1982), in Uranium Series Disequilibrium: Applications to Environmental Problems, M Ivanovich and R. S. Harmon, Editors, Chapter 17, Oxford Science Publications, Clarendon Press, Oxford. 


\section{Appendix A - Analytical Quality Control Data}

\section{Blind Duplicates}

Blind duplicate analyses of marine sediments and fauna

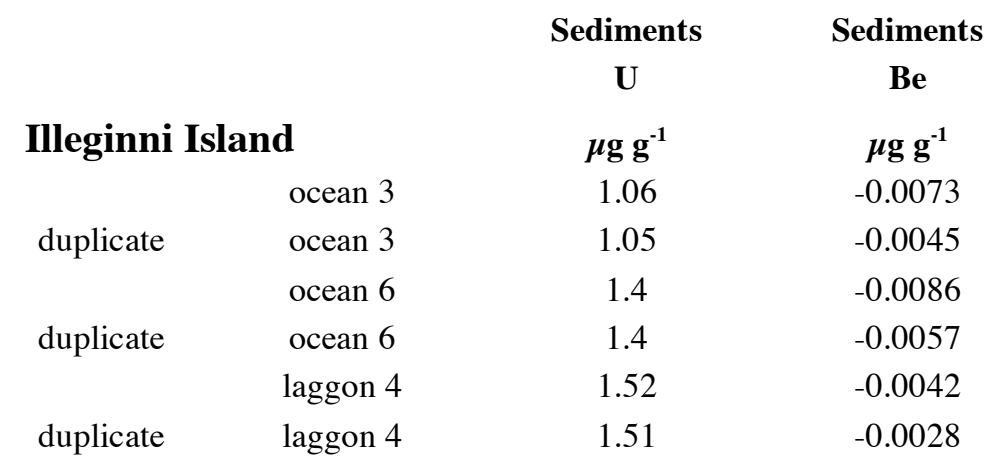

\section{Boggerik Island}

$\begin{array}{llll} & \text { ocean 3 } & 0.376 & -0.0073 \\ \text { duplicate } & \text { ocean 3 } & 0.373 & -0.0059 \\ & \text { lagoon 1 } & 0.655 & -0.0083 \\ \text { duplicate } & \text { lagoon 1 } & 0.657 & -0.0058\end{array}$

\section{Fauna Fauna}

\begin{tabular}{llcc} 
Illeginni island & $\mu \mathrm{g} \mathrm{g}^{-1}$ & $\mu \mathrm{g} \mathrm{g}^{-1}$ \\
\multirow{2}{*}{ duplicate } & ocean & 0.0042 & 0.0077 \\
& ocean & 0.0042 & 0.0073 \\
duplicate & ocean & 0.0054 & 0.0056 \\
& ocean & 0.0050 & 0.0053 \\
duplicate & ocean & 0.0097 & 0.0056 \\
& ocean & 0.0096 & 0.0062
\end{tabular}

Boggerik Island

\begin{tabular}{lccc} 
& lagoon & 0.0060 & 0.0043 \\
duplicate & lagoon & 0.0059 & 0.0043 \\
& ocean & 0.0031 & 0.0048 \\
duplicate & ocean & 0.0033 & 0.0051 \\
\hline
\end{tabular}

